\title{
Sustainable development model for universities in developing countries
}

\author{
Nguyen Hoang Tien
}

\begin{abstract}
The purpose of this article is to provide insight into education systems of developing countries and models of their functioning. The article looks at the balance of business universities in different aspects and angles (both financial and nonfinancial) and finds that the approach that combines different alternative functioning models will make business universities more strategically sustainable. In developing countries there have been a lot of societal and political attentions paid to privatize public universities and/or put more control on private universities. Those attentions should be paid to the alternative models making them more competitive that means effective at a reasonable cost.
\end{abstract}

Index Terms-Business university, competition, performance, measure, finance, research, government, development.

\section{INTRODUCTION}

A t the core of education business, especially the tertiary education, the development orientation of business schools takes place between the two distinct purposes: to produce knowledge (research-intensive) or to educate students (teaching-led) [7]. Some schools are on the extreme edges, while most of them are placed somewhere between with their dual and contradictory rather than cohesive purposes. Financial stability and sustainability of universities, and especially the business universities are only one side of a very complex problem to be thoroughly considered. If we talk about sustainability as a general, we should not have in mind the only financial aspect. As a

Received: Oct 25 $5^{\text {th }}$ 2018; Accepted: Dec $2^{\text {nd }} 2018$; Published: Dec $31^{\text {st }} 2018$.

Author Nguyen Hoang Tien - Thu Dau Mot University (Corresponding author: vietnameu@gmail.com). consequence, both financial and non-financial drivers of business schools' model selection should be put under multilateral analysis and exploration. We then see that the development orientation of business schools is related with more dimensions than simply a question whether to carry out researches, to concentrate on students, or to find themselves a place in-between. Hereafter, 10 of the most important dimensions of business schools' development orientation are subjects of further in-depth discussion and detailed investigative analysis: 1) the origin (private or public), 2) the source of staff (long term contract or teaching hour basis), 3) faculty leader (entrepreneur or professor), 4) textbooks (own or external ones), 5) structure (centralized or decentralized), 6) location and infrastructure (to buy or to hire), 7) language of instruction (local or international), 8) external cooperation (domestic or international), 9) source of funding (state's funding, students' tuition fee, others), 10) value proposition (teaching or researching). According to author's view, those 10 critical dimensions contributing to the proper functioning of business schools and their competition in the tertiary education market should be regrouped into two categories: core issues (that directly impact the quality and competitiveness of education institution), and non-core issues (that indirectly impact the quality and competitiveness of education institution), as follows:

- Core issues (i-v: faculty member staffing, textbooks' quality, language of instruction, value proposition, external cooperation);

- Non-core issues (vi-x: genesis of institution, faculty leader, structural organization, location and infrastructure, source of revenue). 
Both core issues and non-core issues representing the different development orientations of business schools' philosophy and activities are considered the most important for the industry and certainly will impact on the quality of education services, the survival and competitiveness of all institutions. Within those researched core issues and non-core issues identified and mentioned above, we compare common approaches and practices used by Polish universities, representing the Eastern part of Europe and Vietnamese universities, representing the ASEAN, the South-East part of Asia, sometimes referring also to the experiences of other countries in the region, such as India, China, etc., as well as the referring to the reality and trends set by top-level universities in the world, in order to draw interesting conclusions and recommendations at the end of the article.

According to the author, five mentioned coreissues (dimensions) are particularly important for the quality and competitiveness of business education [2]. The author justifies their criticalness and top-priority as follows. In many industries (banking, tourism, healthcare, etc.) of the contemporary economy, especially in education sector, human resources are the most important factor that impacts the quality of services offered. Faculty staff members need long-term, constant training and motivation to develop and contribute to students' future success. Textbooks help student self-study and better understand the knowledge conveyed by the academic teacher. Textbooks should be designed to meet the needs of students and the requirements of curriculum. Textbooks should be an integral, unique and original element of teaching programs, the most important quality's impact factor, just after the teaching staff. Language of instruction is the third important, but it is also related with the first two, in terms of the language used by faculty staff in teaching and carrying research and language of the textbooks issued (or bought) by business schools. Language and its choice are most important means of the education process and are step-stone for the national education development. We couldn't imagine the development of Singapore without adopting English as its official language. In terms of value proposition offered by schools, otherwise the question whether to teach or to focus on research, the answer is both of them are constituent elements of quality, competitiveness and trademark of a given education institution. In tertiary education, teaching activities cannot be without researching activities, not only amongst faculty staff members, but also among students. The studying and teaching activity at the university level itself is just an exciting process of researching exploring and discovering new things. To develop and prosper in an open world, all institution, especially education institution need an extensive and multilateral cooperation with diverse external partners, bodies and peer organizations. It is absolutely a precondition and the top priority for today's organizations' existence and success. The rest, non-core issues are of less urgency as they leave many rooms for choices as supportive elements for the discussed and analyzed above core issues that are critical for the quality and development of business education institutions.

\section{THE ORIGIN - PRIVATE OR PUBLIC}

The first development orientation, rather of macroscopic character, that is often observed and most analyzed by specialists and experts in management of education in post-communist states (such as Poland and all the Eastern Europe) and developing countries (such as China, Vietnam and the rest of ASEAN states excluding Singapore), but not important in highly developed countries such as US and UK is the genesis of a given education institution. In the USA and in other countries, where English is the language spoken natively, all schools, regardless of the origination, compete based on the same market rules and regulations. In the Europe continental, especially in the Central-Eastern countries, and in most of the developing part of the world, those institutions, depending on their originality, compete on different bases, even the different annual rankings are set separately for assessing them and measuring their popularity and 
attractiveness. Hereafter, we'll discuss the advantages and disadvantages of those public and private institutions. Probably, the advantage of the first ones, on the contrary, will be the disadvantage of the second ones.

Public schools in Central Eastern Europe and in other developing countries like China, Vietnam and some of the other ASEAN states have a much longer history of development than private universities, that came into being, like mushrooms after rain, after the start of transitional period of the above-mentioned post-communist countries. Longer development history, on one hand, means more experienced, reliable and professional staff, better infrastructure, guaranteed teaching quality and quality in researches, on the other hand, it is also equivalent to inflexibility and reluctance to diverse changes needed in order to be competitive in a global stage. Public, or other word, state universities are funded partly or mostly from the state budget. In Poland, students don't have to pay for their full-time education in both undergraduate, graduate and even post graduate level and that has been immutable for a long time. In Vietnam, instead, the public universities' tuition fees are extremely low, much lower than the price set by the market. Furthermore, not only public education is funded from state budget, but the research grants are also more accessible and much more open for academic staff of public universities, strengthening at the same time their competitiveness and innovation in the field of scientific research. Public universities' faculties publish more, especially in top-tier international journals. Hence, we can see that, in financial and strategic terms, the advantages and prevails are on the side of public institutions. One more advantage of the public universities is the quality of enrolled students. Due to the free-of-charge education service, public universities attract more capable candidates and the annual entrance exams carried out centrally by the ministry of education (in case of Vietnam) or locally by universities themselves (in case of Poland) each year serve to admit the right ones. In parallel, the advantage of private universities, that should be mentioned, is that they have a right to determine the price of their services offered up to the market conditions, as well as the salary (remuneration system) for academic staff they hired and the framework of cooperation with them (academic staff) also are up to the market conditions, the need and the wish of both sides. As a result, we can see that private universities, in case of headwinds in market conditions, have more rooms to operate in terms of creating, executing and adjusting strategy to adapt to inconsistency and volatility of changing global market, innovation and knowledge-based economy.

\section{SOURCES OF STAFF - ON LONG TERM CONTRACT OR ON TEACHING HOUR BASIS}

The next development orientation, rather of microscopic character, but most important for all the universities in the world, regardless of the origination, the political and economic system of a given country, is how to hire and organized the staff effectively. Taking into consideration the fact that the staff remuneration is a considerable part of the overall cost of functioning universities in developed countries and also the constantly rising part of it in developing countries aspiring to catch up and keep pace in a very competitive and demanding global education market. There are at least three options for those institutions to follow, which are:

- Long term contract - an anchored minimum of teaching hours each year is set up, aside from the obligation of carrying out research, participation in faculty's life. In this case, staff members have more responsibilities and more rights, so they will respect and are more closely connected with their workplace.

- Teaching hour basis - in this case, academic teachers are treated as outsiders on the teach-andgo basis. They teach courses based on the program outlines according to that they have taught elsewhere for many years or in consultation with the program committee in order to conform and comply with specific requirements and standards set by a given university.

- Something in-between - this is the most common option since minimum staff members 
with adequate scientific degrees and nominations is required and imposed as a prerequisite to establish schools and those requirements are controlled and watched carefully by ministerial education inspectors.

Universities are not just the centers of education which function on commercial basis, connecting teachers and students. The competitiveness of the universities with a mission of going global is based on their highly qualified human resources who are competent at teaching and doing researches. So, given university, in order to develop, strengthen its position and compete with others, must, based on long term contracts and commitment, look for talents, invest in development and promoting staff. So have done many American and European universities for a long time before the global crisis erupted in 2008 . In the time when the economy is heading down, many cuts are in execution, not excluding the sector of education. The economic downturn combined with the negative demographical trends has compelled most of European universities including Germany, the economic powerhouse of Europe which is the least vulnerable by the ongoing crisis, to sharply reduce long-term tenure contracts and shift to the teaching hour basis in order to save money to survive. The situation also concerns Poland, not the economic powerhouse, but also the least negatively impacted country comparing to other European economies.

The case of rising ASEAN countries is totally a different history. Despite the impact of the global slump, together with the booming population and the pressing urbanization processes still taking place, the number of students and the need for education are increasing. The sector of education is the most crisis-proof and the least vulnerable among others as many analysts considered. Many wealthy families even choose better option by sending their high school graduates to prestigious universities in the West to benefit from intercultural experiences, English qualification, high quality and standard of education there. Confronting this situation that is still happening both to China, India and ASEAN countries, many universities there, in a bid to improve the domestic education quality, are striving to attract European and American teaching staff offering them very lucrative, long-term working contracts, or wooing Western counterparts to cooperate with them, based on mutual benefits, in a hope to boost their competitiveness and attractiveness in the eye of domestic students, the customers. In the time of economic headwinds for many sectors that hardly survive, this is a light point in the global education scene, understood as a knowledge transfer from the West to the East.

\section{FACULTY LEADER - ENTREPRENEUR OR HIGHLY QUALIFIED PROFESSOR}

The dean or in other words, the faculty leader is very important person for the universities development, as universities are both educational institutions and business institution. Most often, questions are raised in concern with the character of this job position, whether it should be management-oriented with a high load of administrative duties or academic-oriented concentrated on the research development, scientific and teaching quality reputation of the faculty. The problem seems not to be as serious as in developing countries, especially in the region far from largest urbanization centers, where there is not enough qualified human resources in the labor market. In Europe, in America and in other developed part of the world, it is not difficult to find a suitable candidate combining both academic competence and managerial skills even the competition of candidates vying for the prestigious post like this is very fierce. In the second-range cities of Vietnam it is troublesome to find a motivated enough candidate to fill in the post of a faculty leader. Local candidates are familiar adequately with the faculty staff, the character and the working style existing here, but they are not enough academically (or professionally) competent to undertake the job. Candidates from afar, sometimes foreigners, reversely, have a great knowledge, experience and competence, are often not adequate for the job due to incapability to speak local language (English is not enough), unfamiliarity of, and inability to 
cope with the current specific and complicated staff issues of the faculty. In the Western countries, it is incredible for the candidates to fill in the operation position, not mention the management one, if he or she doesn't speak local language and is not familiar with the local life and business practices.

Returning to the education topic, here in developing countries, Vietnam and the rest of ASEAN states, excluding Singapore, for example, a question has been put forwards concerning whether a professor of years of teaching and researching experiences should get the faculty's top job or an authoritative, middle-aged entrepreneur with a Master degree is totally enough if his or her management skills proved by earlier successes in business activities might guarantee the success, both financially and academically, and faculty development as experiences in the world show that many wellknown long-years experienced professors might not have adequate management skills and deep look into the current issues and trends in order to lead the faculty. Due to this fact, in many faculties, especially business faculties in Vietnam's universities the top job is filled in with persons with Master Degree.

\section{TEXTBOOK - OWN VALUE PROPOSITION OR EXTERNAL VALUE PURCHASING}

Textbooks produced written by faculty members are proprietary knowledge. Textbooks, based on the lectures delivered, are the unique value propositions that differ universities one from other. Many faculties and academic teachers normally have two choices, using proprietary, self-created knowledge or basing on well-known external curriculum taught in renowned universities. The statistic data shows that in Western universities, only $10-15 \%$ of the material used in MBA courses was based on teachers' own researches [25]. So what are the propositions for countries that are far or less behind the Western counterparts? In middle-income countries such as Poland, university teachers are not obliged to publish a book, based on that they deliver their lecture, but some teachers, especially full professors, with years of teaching, researching and publishing experience, do so in order to increase their prestige and reliability in the eyes of students. After all, those seniors give lectures mostly in the fields, in which they are deeply engaged in terms of interest and researching activities. In case of Vietnamese teachers, who are teaching-oriented instead of research-oriented, usually are not highly academically advanced and professionally competent in their field. Moreover, they have even several times more teaching duties than their colleagues in the West. Due to the insufficient competence and also due to the lack of times, all of them choose the option of external value purchasing instead of creating their own value proposition, bringing no distinctive value to their institution where they work

\section{STRUCTURE-CENTRALIZE OR DECENTRALIZE}

Many European universities, including Polish ones, are decentralized in terms of general empowerment and academic power transferring from the top down to faculties and lower, with a very strong position of the faculty leaders. But they are centralized in terms of not to establish too many faculties within one university. For example, in Poland, the business university such as Warsaw School of Economics (WSE), the largest one in Central-Eastern Europe, consists of only 5 faculties (collegiums), each of these faculties is divided into as much as 20 departments (WSE 2018). Each of the departments is closely related with specific research fields being a domain of a given faculty. In Vietnam instead, I see the reverse trend. Despite the lack of resources, especially the human resources in terms of highly qualified academic teachers (understood as the number of top academic leaders - professors and associate professors), the decentralizing trend is on the rise and intense. The National Economic University (NEU) in Hanoi, the largest economic university in the whole country in terms of students, academic teachers and carried out researches, is structured down into nearly 20 faculties (NEU 2018). Being incomparable to the Warsaw School 
of Economics in terms of qualified human resources, the teaching and researching capability of each NEU faculties is at the level of WSE' departments. In case of Vietnam and its NEU, decentralization is the simplest way to enhance bureaucracy that desperately should be eliminated. Consequently, WSE's faculties, with an academic potential of about 50 professors each, on behalf of the whole school, have the right to open and close doctoral and habilitation courses, nominate professors for the need of their own teaching and researching activities, that is a sign of decentralization and empowerment. As a contrary, NEU's faculties, with an academic potential of 1 or 2 professors each, have the right to educate postgraduate, master students and open doctoral courses only while theses defense (closing doctoral courses) and professor nomination are executed centrally, out of the reach of NEU and that is a sign of centralization and disempowerment.

\section{LOCATION AND INFRASTRUCTURE - TO HIRE OR TO BUY}

In public universities all over the world, all the things such as location, building and the infrastructure are state-owned and no discussion is needed at all. In case of private universities, the question is about whether to buy or to hire. Many universities in Central and Eastern Europe, due to the lack of capital and shorter history of development than their counterparts in the West, prefer the "hiring" option.

In Vietnam, there always exists very popular thought that if schools do not have their own headquarter, building and infrastructure and so on in order to organize classes and have been pushed to hire all that somewhere, they will be badly credited and positioned lower in the general ranking. This point of view has been widely recognized not only by local and central administrative authorities, but also by all people, students and schools management board themselves. So the main accent is put on the hard sides (buildings and infrastructure) instead of soft sides (knowledge, human capital), that is contradictory to the essence of education sector where the major assets deciding about the advantage and competitiveness of a given institution are just well-trained and qualified human resources. Based on that standpoint, many unproductive investment decisions are made. Many state-owned as well as privately funded universities in Vietnam invest heavily in best locations, magnificent headquarters, buildings and classrooms while the academic staff, in terms of quality and quantity, presents poorly, as well as their remuneration and benefit scheme.

\section{LOCAL OR INTERNATIONAL LANGUAGE OF INSTRUCTION}

Due to the fact that English is the most popular and is an international language in the world, the barriers of introduction of courses taught in English or partly in English should be taken under detailed analysis to draw further going conclusions. English is the most spoken in Western Europe, but the influence of English becomes weaker and weaker heading eastward. One might be sure that the rate of people speaking English in Poland is less than in Nordic countries, France and Germany. English is less spoken in Belarus and Ukraine, but regains increasingly its popularity in Russia and major Asian economies. In general, the level of popularity of the English as a spoken language is measured by the degree of openness of a given economy combined with its size and wealth. Taking this fact under consideration, Vietnam still has a far way to go for the English to be widely and commonly used here.

In Vietnam, many universities, which are situated in largest cities, are pushing themselves to open up and reach out to the world to level up the distances to countries in the region. Towards these ambitious and strategic goals, many of the universities strive to open courses delivered in English based on English textbooks, to push their students to become familiar with foreign language at the very first moments of their study. According to a survey of Intel in Vietnam, among graduates, only $10 \%$ of them are capable to work without further reeducation. But among those $10 \%$, only half of them have adequate English 
proficiency required by the jobs. To improve this situation, here in Vietnam, private schools, more aggressively than their public counterparts, put forward more practical initiative to enhance students' market value after graduation. Many private universities, funded from students' tuition fees, recruit native speakers, increase the weakly English class hours, or even invite foreign professors coming to deliver business lecture in English.

The language problem appears in postgraduate education, mostly delivered in part-time mode and for active professionally groups of older generation. People in the age of 40-ties and 50ties are in the advanced stage of their career, they have money to pay for their relatively expensive executive education, but they are unwilling to take English as a language of instruction or even don't speak it at all. The workable solutions for this contingency are, in case of Vietnamese teacher, lectures should be provided in Vietnamese, in case of foreign teacher, lectures should be translated live into Vietnamese by a third person. The above-mentioned problem is rather precarious since the today's generation of 20-ties and 30-ties learning English from a very young age will become the generation of 40-ties and 50-ties in 10 or 20 years, and then no language barrier will occur.

\section{EXTERNAL COOPERATION - DOMESTIC VERSUS INTERNATIONAL}

International relation and cooperation are the indispensable part of each organization, not only business universities, in context of integration and globalization and the need to reach out to the world. Poland, as well as Vietnam is at different phase of transforming their economy and the international cooperation with developed part of the world only serves them for better. Polish universities, due to their closer geographical distance to the West, gained more advantage on that. Vietnamese universities also try their best and do not want to lag behind while benefiting from traditional relation with France, strengthening at the same time relation with developed countries in the region such as Japan,
South Korea, Singapore and Australia.

In the aspect of domestic collaboration, which will complement the international cooperation in terms of supporting development and bringing mutual benefits, Vietnam differs very much from Poland. Polish universities, after a period of booming, due to current demographical situation, are now confronting the phase of integration and consolidation understood as a traditional merger and acquisition to cut cost and regain a sustainable competitiveness. Vietnamese universities, instead, due to the population being on the rise, urbanization process gaining momentum, need more cooperation than consolidation. Traditionally, private schools need alliances with public ones to benefit from their resources and experience for development purposes, as well as provincial universities closely seek links with partners in the biggest cities for organizing joint education programs [19].

\section{SOURCES OF REVENUE - STATE FUNDING OR STUDENT TUITION}

\subsection{The state funding}

Schools in continental Europe are more or less funded by state budget to educate societal workforce and produce public goods (research products) to generate returns to the nation in terms of productivity and taxes. Education is treated as a public good, so it should be publicly funded to create a long-term benefit for the whole society.

In Asia and Latin America and almost in all the rest parts of the world, the above-mentioned standpoint is being fiercely questioned on the economical (equal market competition between both private and public education institutions) and political (societal competition for public sources) grounds. Education there is perceived largely as a private good so funding should be adjusted accordingly. Furthermore, the so far long-lasting stagnation of the economic situation in Europe finalized by the global economic crisis in 2008 leading to many tough cuts including education sphere increasingly has placed the responsibility to pay for the education on its beneficiaries (the users of services). This process is most visible and 
intensive in Great Britain closing the gap in this area to the United States. In Britain, education was free until 1997, and since then fees have been constantly and sharply raised from symbolic amount of $£ 1000$ in 1998 to a predicted amount of $£ 9000$ in 2012. So do the students' debts and understandably, these are the real burdens for them to repay over a lengthy period once they graduate and get the job.

If the students should be responsible to bear the cost of their tertiary education, a question has been raised about the proportion of high schools graduates to attend universities and the popularity of higher education in a global knowledge-based economy. Despite the British-American for-profit character of tertiary education model, still more high schools graduate there go to universities and colleges than in Europe. In middle-income and developing countries, university attendance rates are the same like in Europe and still rising. In Vietnam, the question is not about whether the government should bear the cost of higher education of its citizens, but the rates of its participation that are very different depending on schools' origination (public or private) and the relation of this policy to the proportion of high school graduates attending universities.

\subsection{Student tuition}

Despite the different models of education extant in the world, the undergraduate tuition fees rise steadily in many countries, whereas postgraduate education programs, mostly in parttime mode, are designed for professionally active people and are treated commercially with tuition fees determined by market and seen as key source of institutions' funding. One of the reasons of this state of fact is that the demand for this kind of education has been increasing drastically over the last 20 years, especially the demand and the price for postgraduate business education with different MBA programs on top of that. The cost of Executive MBA program has been increasing, on average, 10 times since the 1990s [3]. In Europe especially, fees differentiation is based on domestic versus non-domestic students that means the EU students pay less while non-EU students pay several times more. In the USA, tuition fees are extremely high, reaching presently 50 thousand USD a year for undergraduate level and even up to three or four times of that for the Executive MBA programs, plus living expenses combining with the cost of lost opportunities, it lets many students think that the return on investment of their study is unrealistic and they will not be able to repay the loans even for a long time given the current global economic crisis and situation in the labor market [4].

In developing countries like Vietnam, tuition fees differ depending on the origin of a given university, whether it is a state, private or foreign university. Students are not free of charge for their education in public schools, but the tuition fees are covered in $2 / 3$ by state funding and there is an upper limit put on them. Private education costs several time higher or even more. The most expensive is the education at foreign universities operated in Vietnam, among others on franchising basis, with the tuition fees comparable or slightly surpassing studying abroad. The advantage is the cost of living here is much lower but student are deprived of chances to have a real intercultural experience enriching language and communication skills.

\subsection{Other sources of funding}

Executive education on fully commercial basis and fundraising are the main sources of funding, but in time of the economic slump they are not easy to get and are not guaranteed to be successful. Executive MBA education programs require the most sophisticated infrastructure and faculty composition and is very volatile and unstable in terms of income, which may reduce several tens percent during the current economic recession. Fundraising by alumni and partners endowment can be very generous but only accounts for up to a minor part of the funding. In substance, it is also very volatile and concerns only few cases, to mention only the top business universities in the world.

In developing countries only the executive education contributes a major and increasing part 
of the institutions' funding, while fundraising is hardly seen there.

\section{VALUE PROPOSITION - RESEARCH OR TEACHING}

\subsection{Academics-research}

In education business faculty staff is the main asset and it should be managed wisely. In most academic institutions, the overall staffing costs can easily approach $75 \%$ of their total expenditures. Due to this major staffing costs proportion, faculty members' activities, including teaching and research engagement, almost conflicting with each other in nature, while management duties concern only a few of them, should be calculated economically and should be profit-oriented.

In research-intensive university, the faculty members' career paths are dependent on their research productivity. In terms of research activity, the output is measured by the number and the quality of publications, the input effort is hardly to assess due to the fact that research and development activities, not only at universities, are the highly risky ones in the aspect of the cost and time engaged of their carrying out, cost of creating and developing collaborative infrastructures needed to generate high quality valuable commercially or scientifically research products each year.

Management education has been developing since XIX century industrialization, and still fast expanding since the 2th World War. A considerable gap has been seen between key issues on managers' minds and researches published. Many research products are so far irrelevant in terms of informing and shaping management practice as they should do. In other disciplines research and practice are much more closely aligned [15]. Research, regardless of its practical or theoretical orientation, in most cases, is cross-subsidized from teaching income, especially from Executive MBA programs as they often used research papers results as useful case study materials serving teaching purposes.

In many developing countries, the staffing costs are not so much as the above-mentioned proportion in industrialized countries, so does the participation of research in overall academic activities of staff members. Many Vietnamese universities are teaching-led or other word, research-less. The number and quality of published papers of Vietnam are far lagging behind, for instance, Singapore, while the population and the number of students surpass 20 times, possibly due to the simple economic logic of teaching for many newly established universities as we will find out below.

\subsection{Academics-teaching}

A core question of each business school is what does an hour or year of teaching time cost and generate as revenue? Based on that, it is easy to compare different business schools and for a given university to adjust tuition fee policy as well as the remuneration policy. In developed countries such as UK, USA, a teaching-intensive model there is an anchor at about 300 teaching hours per member per year, so the teaching cost is about 270 EUR per hour counted on the presumption that basic faculty salary is of 50 thousand EUR and full loaded is of 80 thousand EUR. Instead, in a research-intensive model, with the reduced teaching load down to 120 hours per member per year the hourly teaching cost is about 1350 EUR counted on the same presumption that basic faculty salary is around 50 thousand EUR and full loaded faculty salary is around 80 thousand EUR. So what is a solution to bring down the cost in case of decreasing number of students (aging society and diminishing birth rate) and current economic headwinds? There are several ways of cost management in terms of drive down it considerably, one is to increase faculty member's teaching load transforming at the same time from research-intensive (teachingless) model to teaching-intensive (research-less) model, the another is to increase the number of students in the classroom leading inevitably to lowering the teaching quality. The third way is to use intensively e-learning technology in educational processes serving cost optimization due to the fact that a large part of management 
education, such as principle courses is suitable to provide online in avoidance to repeat them again and again, while advanced knowledge areas and cases study should be delivered with students face-to-face [1]. On top of the cost management area, the proportion of academic and nonacademic staff should be taken seriously under consideration. Non-academic staff is necessary to take a lot management duty off the hand of academic teachers, expensive and highly qualified resources, for them to concentrate on the core issues. Finally, while the competition for students of management education providers is fierce, the cost of marketing is rising increasingly starting from level of $8-12 \%$ of traditional MBA income stream up to $30 \%$ in case of marketing-intensive private institutions determined to attract large volume of students to fill up the classrooms.

\subsection{Staff career paths - teaching or research oriented}

This development orientation is strictly related with the question concerning staff sourcing. If only short-term contracts are the basis of cooperation, the staff career paths are not important and are not subjects of planning. On the contrary, a question is raised concerning what should be a strategy to promote staff members both financially and non-financially and on what basis to assess them [5]. Whether one should judge them basing on the teaching experience determined by the amount of teaching hours or years, the range of academic courses they offered to students or based on high-quality scientific papers published in top tier journals and academic degrees. It is depending on the education model adopted which are discussed below in the "value proposition" paragraph, that a given university had taken, teaching-less or teaching-led. In developing countries, public universities are not prone to teaching-led model, but somewhere in the middle of this continuum due to still lacking research skills and scientific potential. On the contrary, private universities, with a very short history of development, are profit-oriented, so the teaching-led model is prevailed ever since and nothing is going to change for the moment. So, the career paths of the staff members are depending on teaching as the research activities are treated only as supplemental.

\section{CONCLUSIONS AND RECOMMENDATIONS}

Given the current situation of the business education sector and the results of the abovecarried out analysis, a series of conclusions should be drawn and many recommendations in terms of policy changes for developing countries have emerged in order to keep the most important sector of the knowledge-based economy developing more sustainably. Conclusions and recommendations hereafter are made and put forward based on several dimensional cross-cuts to streamline the business. Traditional sources of income, such as state budget, tuition fees paid by students, executive education and donation are less stable and rather declining in current global context. Schools should adjust their activities accordingly to remain financially balanced. Firstly, in terms of location and infrastructure, option "to hire" is definitely a better one. Schools also should be expanding further in terms of relocation to far-off places to reduce operational costs and to be closer to students. Many Polish universities do this way, opening their branches in smaller towns surrounding biggest cities. Secondly, to be more financially productive, instead of cutting salary and other benefits which only demotivates faculty staff members, schools should be more teaching-oriented by introducing teaching performance related remuneration system $[14,7]$. Nearly all university professors are working somewhere else in the character of independent consultants or seating at boards of directors of different companies. A proposition of tripling their current teaching loads, with other duties and obligations unchanged, is not unreasonable. Moreover, by inviting nonacademic but more practical-oriented lectures from the business world, schools become more vital and more clinical and simply down-tobusiness. In case of Vietnam, the academic staff should increase their research intensity; focus on more practical, for-profit research project in a response to the need of business to bring about 
more income streams to their universities. Finally, as a trend of the XXI century and the global knowledge-based economy, e-learning technologies should be commonly used to provide students with more valuable and more costeffective teaching programs saving time of the faculty staff members, streamlining universities' operational activities.

As said at the start of the article, financial issues are not the only aspect of the sustainable development which needs a multi-aspect and multi-dimensional approach to analysis and investigation. So, the aforementioned approach to streamline the operational functioning of business universities should be complemented with the following remarks concerning the five core issues presented in details in this article. Universities in developing countries need to invest further and heavily in their human resources, the professionalism of faculty staff members, create all conditions needed for them to reach new heights of career development and advancement. It could be done in conjunction with internationalization of the scope of cooperation and exchange with diverse external partners, bodies and peer organizations in the world, using English as the predominant language of teaching, textbooks publication, in carrying out research activities and, more importantly, as official language of all internal and external communication, taking Singaporean model of English adoption as an example or bi-lingual model of other countries in the region (Hong Kong) and in the world (Scandinavian countries in North European). Again, this strategic language choice is the most important for the education process, a step-stone for the advancement of national education system and, as a consequence, for the economic development and overall social prosperity. All in all, the five presented core issues: human resources, textbooks, language of instruction, external cooperation and value proposition, are non-financial factors critical for business universities' sustainable development that should not be special subjects of painful streamline facing the omnipresent cost-cutting trends in business and business education in the world, especially in the time of global crisis and economic vulnerability. Contrarily, those coreissues should be boosted, developed accordingly, in order to bring about multiple values for the business education institutions that are desperately looking for new means of innovative competition and development.

\section{REFERENCES}

[1]. Barolli, E., \& Sevrani, K. (2009). Reflection on elearning readiness in Albanian education. Contemporary Economics, 9(1), 5-18.

[2]. Bone, D. (2009). Universities in a Global Context: How is Globalization Affecting Higher Education? House of Commons Seminar, $27^{\text {th }}$ January 2009.

[3]. Brown, R. (2011), "Lesson from America", Higher Education Policy Institute report. www.hepi.ac.u/4841936/:essons-from-America.html.

[4]. Byrne, J. (2011), "The world's most expensive MBA program". www.poetsandquants.com

[5]. Estermann, T., \& Claeys-Kulik, A. L. (2013). Financial Sustainable Universities. Full Costing: Progress and Practice. European Universities Association.

[6]. http://www.eua.be/Libraries/publications-homepagelist/Full_Costing_Progress_and_Practice_web.pdf?sfvrs $\mathrm{n}=2$, date of access: 02/08/2018

[7]. Fragueiro, F. and Thomas, H. (2011), Strategic Leadership in the Business School: Keeping One Step Ahead, Cambridge University Press, Cambridge.

[8]. Fram, E. H., \& Lau, G. H. (1996). Research universities versus teaching universities - public perceptions and preferences. Quality Assurance in Education, 4(3), 27-33.

[9]. Greenwell, B. M. (2017). Business Strategies to Increase the Financial Stability of Private Universities. Doctoral dissertation at Walden University, August 2017.

[10]. https://scholarworks.waldenu.edu/cgi/viewcontent.cgi?a rticle $=4877 \&$ context $=$ dissertations, date of access: $02 / 08 / 2018$

[11]. Hood, C. (1991). A public management for all seasons? Public Administration, 69, 3-19.

[12]. Howard, T., \& Kai, P. (2012). A sustainable model for business schools. Journal of Management Development, 31(4), 381. (DOI 10.1108/02621711211219031)

[13]. King, R., (1995). What is higher education for? Strategic dilemmas for the twenty-first century university. Quality Assurance in Education, 3(4), 1420.

[14]. Lorange, P. (2008), Thought Leadership Meets Business: How Business Schools Can Become More Successful, Cambridge University Press, Cambridge. 
[15]. McGrath, R. G. (2007), "No longer a stepchild: how the management field came into its own", Academy of Management Journal, Vol. 50 No. 6, pp. 1354-78.

[16]. OECD (2010), "Education at a Glance", OECD, Paris.

[17]. Osborne, D., \& Gaebler, T. (1991). Reinventing Government: How the Entrepreneurial Spirit is Transforming the Public Sector, New York: Plume.

[18]. NEU 2018 - www.neu.edu.vn

[19]. Nguyen Hoang Tien (2017): International Executive MBA Study Program as Part the of International Cooperation Strategies of the Universities. Conference on "Perspectives of International Cooperation of the Universities", October 2017, University of Pedagogy, Ho Chi Minh City.

[20]. Robertson, S. L. (2010). Challenges Facing Universities in a Globalizing World. Centre for Globalization, Education and Societies, University of Bristol, Bristol BS8 1JA, UK. Accessible at: http://susanleerobertson.com/publications/

[21]. Rynca, R., \& Radomska, J. (2009). Strategic dilemmas of universities. Contemporary Economics, 11(3), 87-93.

[22]. Takeuchi, H. (2004). Knowledge Creation and Dialectics. In: Hitotsubashi on Knowledge Management, by Hirotaka Takeuchi and Ikujiro Nonaka. John Wiley \& Sons.

[23]. Taylor, M. (2011), "A weather eye on the US storm", Times Higher Education, 24 February, p.35.

[24]. Todose, D. (2008). Education management in knowledge based society. Contemporary Economics, 7(3), 109-117.

[25]. Van Hoek, R. I. and Peters, B. K. G. (2008), "(Does research make it into the classroom and does it matter?", Tijdschrift voor Hoger Onderwijs, Vol. 26 No. 3, pp. 180-9.

[26]. WSE 2018 - www.sgh.waw.pl.

\title{
Mô hình phát triển bền vững cho các trường đại học tại các quốc gia đang phát triển
}

\author{
Nguyễn Hoàng Tiến \\ Trường Đại học Thủ Dầu Một \\ Email tác giả liên hệ: vietnameu@gmail.com
}

Ngày nhận bản thảo: 25-10-2018; Ngày chấp nhận đăng: 2-12-2018; Ngày đăng: 31-12-2018.

Tóm tắt—Mục tiêu của bài viết này là nhằm cung cấp tổng quan về hệ thống giáo dục của các quốc gia đang phát triển và các mô hình đang được áp dụng. Bài viết nghiên cứu các trường đại học kinh doanh dưới nhiều khía cạnh và góc độ (cả về mặt tài chính và phi tài chính). Kết quả cho thấy phương pháp kết hợp các mô hình chức năng khác nhau giúp cho các trường đại học kinh doanh bền vững hơn về mặt chiến lược. Tại các quốc gia đang phát triển, công chúng rất quan tâm đến các tác động xã hội và chính trị của việc tư nhân hóa các trường đại học công và/hoặc yêu cầu kiểm soát chặt chẽ hơn các trường đại học tư. Tuy nhiên, sự quan tâm này nên được dành cho các mô hình giúp gia tăng khả năng cạnh tranh cho các trường đại học, nghĩa là hiệu quả với chi phí hợp lý.

Tù khóa-Trường đại học kinh doanh, cạnh tranh, kết quả hoạt động, biện pháp, tài chính, nghiên cứu, chính phủ, phát triển 